\title{
I'll be back
}

Carlos Andrés Arango ${ }^{1}$

DOI: 10.5294/pacla.2017.20.2.11

Reseña del libro: Roncallo-Dow, S., Uribe-Jongbloed, E. y Goyeneche-Gómez, E. (2016). Volver a los clásicos: teorías de la comunicación y cultura pop. Bogotá: Universidad de La Sabana.

Decía Italo Calvino que los clásicos son aquellos libros que todo el mundo cita pero nadie lee. La necesidad de la mentirilla viene a ratificar que, en el fondo, no es necesario leer los dos volúmenes de El Quijote para saber que se trata de un caballero un poco corrido de la teja, con episodios que involucran a unos molinos, a un coequipero de nombre Sancho y a una Dulcinea de dudosas dotes estéticas que el caballero de la triste figura veía como a la más bella de las mujeres.

Mas, si bien clásico es un término complejo en el que tanto caben los "clásicos del reguetón", los jeans, o el cine de Chaplin, la idea que surge en este libro es clara: los clásicos son aquellas teorías, tesis, puntos de vista, conceptos que definieron algo con tal contundencia que volver a ellos, aunque pasen los años, sigue siendo necesario, significativo y aportante.

En este caso, se trata de los clásicos de la teoría de la comunicación, releídos a la luz de lo que los nuevos tiempos nos dejan en materia de cultura pop. Sabemos que fueron necesarios muchos debates antes de que en los círculos más ortodoxos de los estudios sobre cultura y estética se admitiera que "cultura pop" y "clásicos" cupieran en una misma línea. Marshall McLuhan, Walter Benjamin, Umberto Eco, Roland Barthes y Theodor Adorno hicieron aportaciones críticas para que esto fuera posible. Y por ello, junto a otros grandes nombres, están aquí revisitados, en el contexto de una labor

1 orcid.org/0000-0002-2120-3304. Universidad Católica de Oriente, Colombia. carango@uco.edu.co 
hermenéutica encomiable: ir a las páginas de los textos originales, extraer lo esencial, actualizar las fenomenologías que ocuparon la atención de los investigadores y correlacionarlas con problemáticas del presente.

No es mínimo el alcance de este ejercicio. De ello dan cuenta las decenas de ejemplos de la cultura pop que desfilan por estas páginas, las citas de valioso aporte que se extraen de los clásicos (que escapan a las ya famosas que una y otra vez se traen a las páginas de investigación en comunicación) y los análisis que se aplican con juicio y rigor a temáticas como el videoclip, los alienígenas, Facebook, los seriados policiales y las cirugías plásticas. Estamos ante un libro en el que las referencias a canciones del rock de los noventa conviven con citas a Benjamin, libros de cómic y fragmentos autobiográficos desde los cuales los autores conectan su experiencia vital con la reflexión que emprenden en este volumen de 191 páginas.

Pero además del ejercicio de revisitar las teorías clásicas a la luz de los clásicos contemporáneos de la cultura de masas (sí, admitámoslo: las selfis son ya parte del canon de clásicos de la cultura pop), el libro se presenta a sí mismo como una realidad palimpsestual, polifónica y a menudo desconcertante. Es decir, leerlo es ya una experiencia. La multiplicidad de voces, el cambio de primera a la tercera persona, la conmutación entre el "yo" y el "nosotros", y la excelente narración, harán de su lectura algo retador y, por lo mismo, divertido.

Eso sí: aquellos lectores interesados en los manuales, las guías técnicas o las compilaciones a modo de recetario no parecen reunirse en el perfil de lector que busca ( $y$ que merece) este libro. Los pensamientos fundamentales de los autores clásicos sí están tanto como algunos datos historiográficos y biográficos de los escritores que siempre aparecen en las clases de historia de las teorías de la comunicación. Es solo que aquí están para algo más que conformar un corpus de frases célebres y fechas memorables. Por el contrario, reavivar la voz de un Laswell o un Shannon cobra sentido cuando sus ecos nos ayudan a agudizar la mirada una vez la sacamos de las páginas de Volver a los clásicos y la dirigimos a la televisión, el celular o a la calle. Por tanto, conviene dejarse de prejuicios y aceptar el recorrido por los capí- 
tulos como un ejercicio de pensamiento, siguiendo las palabras de Borges, según las cuales el libro no es la extensión de los ojos, sino del pensamiento. El medio es el mensaje.

Y también la ruta que los autores eligen para su proceso de exposición (en el sentido de "describir" y en el de "exponerse"). Siguiendo las configuraciones teóricas de la comunicación, el texto comienza con una revisión del funcionalismo en clave de la pregunta por los efectos de los medios de comunicación. Esta vez, de la mano del fenómeno de los alienígenas en los medios masivos, el libro revisa los postulados fundamentales de una escuela con la cual se inauguraron los estudios en comunicación, en cuyas obras clásicas se aprecia tanto la fantasía totalitaria del control mental como la pregunta de hondo calado sociológico por la forma en que la transmisión masiva de información pudiera afectar las estructuras convencionales de la vida social. Si algo nos permiten ver los autores de Volver... es que la sospecha funcionalista, con todo y su acepción mecanicista de la comunicación, no estuvo desenfocada cuando señaló su temor por lo que se venía.

Así, desde la premisa de un cambio social generalizado promovido por los medios masivos, centro epistemológico y ontológico del funcionalismo, el libro avanza a una revisión del videoclip, de matiz semiológica, donde cabe la inspección por el signo en clave de relato audiovisual e industria musical: lo que escuchamos es posible, sobre todo, por lo que nos sugiere ver. Esa fusión del contenido, el discurso y la mediación se indaga también a propósito de YouTube y el aura artística: ¿por qué un video se viraliza? Porque en la cultura pop el aura no viene de la mano de la exclusividad en la visualización-disfrute de la obra, sino, por el contrario, de esa cierta legitimidad que les otorga a los videos un número abultado de visualizaciones en la plataforma.

Esa misma agudeza se deja ver en la lectura crítica de la fotografía como lenguaje, el álbum de laminillas fotográficas de futbolistas, el fenómeno de las selfis y los seriados enlatados: si la economía es la pregunta por el valor, cabe indagar sobre esas nuevas formas de valor que se aplican en la construcción de una imagen-marca, donde los sujetos entran en el intercambio 
de transacciones a partir del precio que tiene aparecer en un lugar, postear imágenes de un viaje o completar el álbum Panini. Aquí los principios teóricos de la economía de la comunicación entran a ponderar el (¿nuevo?) valor de la imagen como portadora ya no solo de signos sino de valores simbólicos, y todo se lee como un correlato del consumo: estamos dispuestos a pagar por ver en cuanto el imaginario se concentra en torno a idear estrategias para que también nos vean.

Con todo, este recorrido polémico, sugerente y abigarrado de referencias es una contribución destacada al ejercicio teórico de revisar la actualidad y validez de las teorías, con miras siempre a probarlas, contrastarlas $y$ tomar un juicio propio. Hablamos de un libro necesario, bien narrado y que nos invitará una y otra vez a pensar la comunicación. 